This is a self-archived version of an original article. This version may differ from the original in pagination and typographic details.

Author(s): Salminen, Timo; Marttunen, Miika; Laurinen, Leena

Title: Argumentation in secondary school students' structured and unstructured chat discussions

Year: 2012

Version: Accepted version (Final draft)

Copyright: (c) Authors, 2012

Rights: $C C$ BY-NC-ND 4.0

Rights url: https://creativecommons.org/licenses/by-nc-nd/4.0/

Please cite the original version:

Salminen, T., Marttunen, M., \& Laurinen, L. (2012). Argumentation in secondary school students' structured and unstructured chat discussions. Journal of Educational Computing Research, 47(2), 175-208. https://doi.org/10.2190/EC.47.2.d 


\title{
Argumentation in Secondary School Students' Structured and Unstructured Chat Discussions
}

Timo Salminen (the corresponding author), Miika Marttunen, \& Leena Laurinen University of Jyväskylä, Finland

P.O.Box 35 (Viveca 157), FI-40014 University of Jyväskylä, Finland +358-408053649, Fax +358-14-2601761, timo.salminen@,jyu.fi

\begin{abstract}
Joint construction of new knowledge demands that persons can express their statements in a convincing way and explore other people's arguments constructively. For this reason, more knowledge on different means to support collaborative argumentation is needed. This study clarifies whether structured interaction supports students' critical and elaborative argumentation. The study compares the quality of secondary school students' argumentation during structured and unstructured chat interaction. The data consist of 16 dyadic chat discussions. Eight discussions concerned vivisection and eight gender equality. Half of the discussions were carried out through structured chat, and the other half through unstructured chat. The results suggest that a structured chat environment evokes counterargumentation, also in topics that do not spontaneously provoke conflicting viewpoints. Further, structured chat seems to equalise communication between females and males. Overall, the results indicate that the further investigation and design of pedagogical means to structure collaborative argumentation is a worthwhile enterprise.
\end{abstract}

Keywords: collaborative argumentation, counterargumentation, knowledge construction, secondary school, structured chat 
Argumentation in Secondary School Students' Structured and Unstructured Chat Discussions Today's social, cultural, political and environmental realities have implications for thinking and learning, business and politics, human rights, and human conflicts (Paul \& Elder, 2002). These realities are so complex and dynamic that advanced thinking skills are required to make sense of the world. Such thinking skills include the ability to express our thoughts in a convincing way, as well as to judge other people's views and arguments constructively. For this reason, the ability to put forward, develop and evaluate arguments has been regarded as an important academic goal in secondary school (e.g., Marttunen, Laurinen, Litosseliti, \& Lund, 2005).

Argumentation can also be seen as a means to learn. Engaging in argumentative discussion with peers helps students to broaden and deepen their viewpoints (see van Amelsvoort, 2006). Furthermore, Zohar and Nemet (2002) stated that argumentation skills are transferable, as reasoning abilities learned through argumentative discussions on a particular topic can also be applied in discussions in other areas. However, it has been shown that both adolescents (e.g., Chan, 2001) and university students (Marttunen, 1997) have difficulties in mastering argumentation skills.

Consequently, there is a need for learning environments which both promote students' argumentation skills and foster the acquisition of dialogical communication skills. In addition, formal learning environments should be meaningful for students in their everyday lives in one way or another. According to Dons (2008), a bridge must be built to span the digital gap between the culture of school and the technology culture of young people. Collaborative argumentationbased learning environments with chat facilities could bring these two cultures closer. However, in addition to utilising new learning technologies, pedagogical practises need to be developed. 
This study responds to these challenges by focusing on the question of whether structured chat interaction promotes secondary school students' critical and elaborative argumentation and knowledge co-construction. The study compares secondary school students' argumentation during structured and unstructured chat discussions.

\section{Argumentation and Learning}

Argumentation and learning are often intertwined, and their relationship is twofold (Schwarz, 2009). On the one hand learning to argue means the acquisition of the skills needed during argumentation, such as being able to justify one's own claims, challenge others' claims and arguments, and respond to challenges by presenting counterchallenges. On the other hand arguing to learn entails, for example, learning new ideas or clarifying old misconceptions through argumentation. When one student challenges his/her peer in a classroom debate, $\mathrm{s} / \mathrm{he}$ is simultaneously both practising argumentation and constructing new knowledge (Schwarz, 2009).

Argumentation has an important role in collaborative learning, as joint reflective and critical reasoning through dialogue has been seen as a prerequisite for collaborative learning (e.g., Mercer, 1996). Collaborative learning can be achieved by means of collaborative argumentation in which the participants strive towards the common goal of attaining a better understanding of the issues in question by putting forward different points of view, claims and arguments, and by exploring them in a deep and critical way (Litosseliti, Marttunen, Laurinen, \& Salminen, 2005). Accordingly, Golanics and Nussbaum (2008) stated that collaborative argumentation is a social process in which individuals work together to construct, critique and judge arguments.

Learning has often been seen as an active knowledge construction process, and argumentation has been seen as an essential means to keep this process alive (Dillenbourg \& 
Schneider, 1995). Nussbaum (2008) emphasizes the importance of sociocognitive conflict and cognitive elaboration, as mechanisms associated with collaborative argumentation, in fostering knowledge construction and learning. From the Piagetian point of view, sociocognitive conflicts are essential in a person's learning. Such conflicts arise when one notices a difference between one's prior knowledge and one's new knowledge obtained through dialogue with other people (e.g., Webb, 1995). Sociocognitive conflicts are typical of argumentative dialogue when various opinions, and arguments in support of them, are presented. During the conflict-solving process people explore the controversial issue together and refine their earlier conceptions to gain more elaborated and better reasoned knowledge. According to the cognitive elaboration theory, argumentation stimulates deeper learning (O’Donnell \& King, 1998). Argumentation may trigger students to generate connections between concepts and prior knowledge (Wittrock, 1992), to repair their mental model about the learned domain (deLeeuw \& Chi, 2003), and to examine and adopt alternative conceptions (Reiser, Tabak, Sandoval, Smith, Steinmuller, \& Leone, 2001). In other words, argumentative elaboration can be seen as knowledge integration (Linn \& Elyon, 2000). Constructive engagement in collaborative and elaborative argumentation requires those involved to carry out two processes: justification and negotiation (Leitão, 2000). The participants need to support their claims by giving reasons to justify their positions, and they need to examine and refine their claims when opposing claims have been presented.

From the Vygotskian point of view, counterargumentation connects interpersonal and intrapersonal processes. The interplay between these two processes leads to the construction of knowledge. Counterarguments enable students to move on from old to new perspectives on a topic (Leitão, 2000), i.e., to broaden and deepen the space of debate, as van Amelsvoort (2006) put it. Leitão (2000, p. 336) emphasises that the value of a counterargument is to call a speaker's 
point into question and give people grounds for examining their own views, not to falsify a claim. According to Nussbaum and Kardash (2005), people do not usually realize that rebutting opposite points of view also often increases the persuasiveness and credibility of their own arguments. In the study by Leitão (2003), for example, more than a half of the sample of college students (aged 18-19 years) viewed counterargumentation as a negative rhetorical strategy and thought that it would reduce the probability of the viewpoint being acceptable. On the other hand, it has been shown that examining counterarguments may polarize positions (Leitão, 2000) and create social inhibition that may hinder learning (Andriessen \& Schwarz, 2009). For example, if students adopt an adversarial style of communication, in which disagreements are overt, they are unlikely to consider their conflicting views together (Asterhan \& Schwarz, 2007). Such an adversarial style does not promote understanding of an issue.

Leitão (2000) presented three strategies to formulate counterarguments, each of which has different implications for learning. The first counterargumentation strategy proposed by Leitão (2000) is that counterarguments can be used to refute either the other person's position or arguments associated with it. Through this kind of counterargumentation a person can indirectly support his/her own claim or position. This strategy is not a dialogical and constructive way to think critically, as it does not call into question the merit of the speaker's own argument. It also enables one to shift the focus of argumentation to the views expressed by the other person. Thus, this strategy is not a productive way to construct knowledge collaboratively.

Second, counterarguments can also be used to question the truth of a claim or a statement the other person has presented. This means that a person can dismiss a point merely by denying it or s/he can put forward a statement that may reverse the claim. The successful use of this counterargumentation strategy requires that a person has sufficient knowledge on the topic under 
discussion to be able to express a justified disagreement. The arguer should also consider how defensible his/her opposing view is. Nevertheless, the use of this strategy enables students to bring more relevant and accurate knowledge into discussion.

Third, a person may also use counterarguments to question a reason-position link included in the interlocutor's speech. When using this strategy the person has to use his/her knowledge of argument schemes, i.e., the logical structure of informal arguments (e.g.,Walton, 2006), to challenge the other person's grounded position by indicating weaknesses in the link that connects the grounds with the position. In argumentative discussions these links are frequently implicit, but during discussions on controversial topics the links between positions and arguments are likely to be questioned when they are made explicit and thus defensible. This strategy challenges a person to express more valid grounds to strengthen his/her arguments. The arguers also get practise in how to use such argument schemes more accurately.

\section{High Quality Argumentative Discussion}

High quality argumentative discussion is task-focused (Veerman, Andriessen, \& Kanselaar, 2000). This means that students have to maintain a shared thematic focus during the discussion. Veerman et al. (2000) stressed that task-focused discussion enables students to engage both in critical argumentation, when they check, assess, challenge, and counter information, and in the production of constructive activities such as adding, explaining, evaluating, summarizing, and transforming information. A good argumentative discussion is also balanced (Baker, Quignard, Lund, \& van Amelsvoort, 2002). This means that there must be arguments both for and against the topic under discussion.

According to Felton (2004), the quality of argumentative discussion relies on the mastery of two sets of cognitive skills: argument construction and discourse strategy. Argument 
construction entails that a person can produce claims, arguments, justifications for arguments, counterarguments, and rebuttals to counterarguments. In a reciprocal interaction, topically related argumentative moves constitute argument sequences. The more argumentative moves in argument sequences, the more elaborative the argumentation is (Andriessen, Erkens, van de Laak, Peters, \& Coirier, 2003). This facilitates learning, i.e., co-construction of knowledge in order to gain a better understanding of the topic.

The purposeful use of discourse strategies means that a person is able to direct and manage discussion with questions, critiques and rebuttals (Felton, 2004). This skill is also required to gain profit by argumentation in a dialogic context. Felton and Kuhn (2001) compared adolescents and young adults in the use of argumentative strategies when they discussed capital punishment in pairs. They found that extending or elaborating the partner's preceding utterance, and asking clarifying questions were more frequent strategies among adolescents than young adults, whereas interpreting (paraphrasing), counterarguing, and rebutting were more frequent strategies among young adults. The strategies of young adults were characteristic of more advanced argumentative discourse, as well as expert discourse.

\section{Chat-Based Argumentative Interaction}

It has been indicated that participants' engagement in cognitively high-level collaborative activities such as questioning, negotiation, reasoning and argumentation is rare in virtual collaborative environments (e.g., Arvaja, Rasku-Puttonen, Häkkinen, \& Eteläpelto, 2003). Synchronous computer-based interaction compared to asynchronous interaction may, however, offer advantages in promoting students' argumentative activities. According to Condon and Cech (1996), synchronous chat interaction clarifies students' thinking because the need for brevity during interaction may cause students to articulate their opinions and arguments more precisely. 
Morgan and Beaumont (2003) also found that chat interaction helped students to express more relevant, well-grounded, and logical arguments, and to offer examples and justifications more sharply to the point. Furthermore, in the experimental studies by Veerman (2000), synchronous computer-mediated communication contained more counterargumentative speech acts than asynchronous communication.

Chat-based communication may also cause a number of problems for knowledge construction and learning. Chat-based interaction may suffer from incoherence of contributions, lack of coordination and focus, and insufficient feedback due to the lack of non-verbal communication (Herring, 1999; Pimentel, Fuks, \& de Lucena, 2003). Furthermore, Burnett (2003) points out that due to the nature of chat as a communication channel, it is difficult to explore ideas in any depth or to explain the argumentative relations between claims, reasons and justifications. Weger and Aakhus (2003) also found that arguments during chat interaction tended to be underdeveloped or unresponsive to those raised by other participants.

The problems encountered during chat communication can be overcome using both didactical and communicational means (Oehl \& Pfister, 2010). Didactical means may include the use of particular combinations of collaborative activities, such as task sequencing, role-playing, scripting or structuring. For example, students' interaction processes have been structured by using scripted collaboration and this has been shown to be beneficial for learning (Hämäläinen, 2008; Weinberger, Ertl, Fischer, \& Mandl, 2005). Furthermore, Baker and Lund (1997) found that students' structured interaction was more reflective than their unstructured communication.

Communicational means may comprise the use of particular discourse units, such as adjacency pairs (question-answer, counterargument-rebuttal), prompts, or sentence openers to produce successful learning interaction. Hron, Hesse, Cress, and Giovis (2000) showed that 
structuring discussion by using prompts (microscripts), such as questions or rules for discussion, can help to maintain focus on the subject matter, decrease off-task talk, and lead to a more coherent discussion. McAlister (2004) used the AcademicTalk tool with sentence openers (such as "Can you give an example...?", "I disagree because...”) and found that students addressed previous arguments more clearly and examined and challenged more arguments compared with students using unstructured chat. However, students do not always use sentence openers in an intended way (Robertson, Good, \& Pain, 1998), but instead tend to use the most generic sentence openers like "I think..." (McManus \& Aiken, 1996). Students also reported that sentence openers excessively restrict their communication (Lazonder, Wilhelm, \& Ootes, 2003). For these reasons, more attention should be paid to the creation of appropriate conditions and suitable tasks when using chat for constructive argumentation.

\section{Research Hypotheses}

In this study upper secondary school students studied vivisection and gender equality by engaging in argumentative discussions through chat facilities. The study aims at clarifying whether dyadic discussions through structured and unstructured chat affect the quality of students' argumentation. The structured chat used in this study was based on the use of sentence openers designed to stimulate argumentative discussion between students. The quality of the students' argumentative discussions was examined by clarifying how they constructed arguments, dealt with disagreements (counterargumentation), and directed and managed their interaction during chat discussions. The following research hypotheses were addressed:

1. Secondary school students are able to construct arguments and manage argumentative chat discussions (see Litosseliti et al., 2005; Veerman, 2000). 
2. Students use constructive counterargumentation strategies (Questioning the truth of a claim or a statement, Questioning a reason-position link) more than the strategy "Supporting the opposite position" that is not a dialogical strategy to construct knowledge together (see Leitão, 2000).

3. The mode of chat (structured vs. unstructured; see McAlister, 2004), the discussion topic (vivisection vs. gender equality; see Golder \& Pouit, 1999), and gender are associated with the quality of the discussions.

\section{Method}

\section{Participants}

The participants; 10 female and 7 male (aged 16-17 years) upper secondary school students; enrolled in a course on Finnish language (mother tongue) and literature in a Finnish secondary school. Before participating in the study the students had already been taught the main principles of argumentation and the main features of the technological tools used in the course.

\section{Teaching Arrangements}

A quasi-experimental counterbalanced design (Borg \& Gall, 1989) was applied in the study. The students were divided into two groups and their discussions were carried out in two sessions on different days with two chat tools and two topics (Table 1). The discussion topic for the first session was vivisection and gender equality for the second session. In the 1 st session, group 1 engaged in the discussions through unstructured chat, and group 2 through structured chat. In the 2nd session, the order was reversed. 
Table 1.

Design of the Study

\begin{tabular}{lll}
\hline \multirow{2}{*}{ GROUP } & SESSION & \\
\cline { 2 - 3 } Group 1 & $\mathbf{1}^{\text {st }}$ session, day 1 & $\mathbf{2}^{\text {nd }}$ session, day $\mathbf{2}$ \\
\cline { 2 - 3 } Group 2 & Vivisection, unstructured chat & Gender equality, structured chat \\
\hline
\end{tabular}

Table 2.

Organisation of the Chat Discussions

\begin{tabular}{|l|l|}
\hline PHASE & ACTIVITY \\
\hline \multirow{2}{*}{$\begin{array}{l}\text { Introduction } \\
(20 / 35 \mathrm{~min})\end{array}$} & $\begin{array}{l}\text { Students trained with the unstructured and structured chat tools }\left(1^{\text {st }} \text { session, } 25 \mathrm{~min}\right) . \\
\text { and engaged in general discussion on gender equality }\left(2^{\text {nd }} \text { session, } 20 \mathrm{~min}\right) .\end{array}$ \\
\hline $\begin{array}{l}\text { Preparation } \\
(20 \mathrm{~min})\end{array}$ & Students read three articles on the topic in both sessions. \\
\hline $\begin{array}{l}\text { Debate }(15 \\
\text { min })\end{array}$ & $\begin{array}{l}\text { Half of the students engaged in debate through unstructured chat and the other half through } \\
\text { structured chat in both sessions. }\end{array}$ \\
\hline
\end{tabular}

The chat discussions consisted of introduction, preparation, and debate phases (Table 2). During the introduction phase (20/35 minutes), the students were taught how to use the unstructured and structured chat tools. To enhance the students' motivation towards the topics, they were asked to fill in a cloze test on vivisection and discuss gender-related topics on working life and vocational counselling. During the preparation phase (20 minutes) the students read three articles containing arguments both for and against the topic. The students were asked to think about the different viewpoints on the topics presented in the texts and how the viewpoints were supported.

During the debate phase the students engaged either in structured or unstructured chat discussions in pairs for 15 minutes. The teacher formed the student pairs so as to maximise the number of mixed gender pairs (see Swann, 1992). She also paired students whom she knew could work well together (see Blatchford, Kutnick, Baines, \& Galton, 2003). There were 6 girl- 
boy pairs and 2 girl-girl pairs in the $1^{\text {st }}$ session and 7 girl-boy pairs and 1 girl-girl pair in the $2^{\text {nd }}$ session. The students were asked to discuss the topic-related claims Vivisection should be allowed / There is gender equality in Finland on the basis of the articles they had read.

\section{Chat Tools Used by the Students}

The unstructured chat used by the students was regular synchronous textual chat integrated into an Internet-based learning environment (see Corbel, Girardot, \& Jaillon, 2002). The structured chat tool (see Hirsch, Saeedi, Cornillon, \& Litosseliti, 2004) consisted of four categorised sets of either full or partial sentences called templates (Table 3): (a) Argument (ask for and express an argument for or against a statement, (b) Explore (ask for and express a clarification of or justification for a statement, discover a problem between statements, or retract a statement), (c) Opinion (ask for an opinion, express agreement or disagreement without giving reasons, and express changed opinions about a statement without giving reasons), and (d) Comment (expressions relating to social, task or interaction management of the debate). The templates are based on certain regular patterns of argumentative strategies and rhetorical moves, and contain a reference to one or more previous statements. In this study, the purpose of the templates was to structure students' interaction and to stimulate their argumentation.

Table 3 illustrates how the students used the templates in debating gender equality. The templates are given in regular font and examples of the students' contributions in italics; "X" refers to the number of a speech turn. 
Table 3.

Examples of the Use of the Templates of the Structured Chat

\begin{tabular}{|c|c|}
\hline TEMPLATE SET & TEMPLATE \\
\hline Argument & $\begin{array}{l}\text { 1) Can you give an argument for statement X? } \\
\text { 2) I support statement X because several Finnish women have gone a long way in our } \\
\text { country. } \\
\text { 3) Can you give an argument against statement X? } \\
\text { 4) I attack statement X because men are not yet equally making their way into "female } \\
\text { domains". }\end{array}$ \\
\hline Explore & $\begin{array}{l}\text { 5) Can you clarify statement X? } \\
\text { 6) I would like to clarify statement X by saying that in general gender equality is a fact. } \\
\text { 7) There is a problem between statement X and statement Y because men have full } \\
\text { freedom to enter "female domains". } \\
\text { 8) I retract statement X because the attitudes of society and of my friends greatly affect } \\
\text { the situation. } \\
\text { 9) Can you give an example to justify statement X? } \\
\text { 10) I would like to justify statement X by saying that in our school there is a nameless } \\
\text { male teacher of maths who cannot understand that girls can be good in maths as well. }\end{array}$ \\
\hline Opinion & $\begin{array}{l}\text { 11) I don't agree with statement } X \text {. } \\
\text { 12) I agree with statement } X \text {. } \\
\text { 13) I changed my opinion about statement } X \text {. } \\
\text { 14) What is your opinion about statement } X \text { ? }\end{array}$ \\
\hline Comment & $\begin{array}{ll}\text { 15) Hello! } & \text { 19) Hurry up! } \\
\text { 16) Bye! } & \text { 20) Slow down! } \\
\text { 17) My turn. } & \text { 21) I would like to talk about statement X. } \\
\text { 18) Your turn. } & \text { 22) I see what you mean. }\end{array}$ \\
\hline
\end{tabular}

\section{Data}

The data consist of 16 dyadic chat discussions (Table 4). Eight debates were carried out by structured chat, and eight by unstructured chat. The total number of speech turns was 609 . The ten female students presented 335 (55\%) speech turns, and the seven male students 274 (45\%) speech turns. 
Table 4.

Data of the Study

\begin{tabular}{llcc}
\hline Mode of chat & Topic & $\begin{array}{c}\text { Number of chat } \\
\text { discussions }\end{array}$ & Number of speech turns \\
\hline Structured & Vivisection & 4 & 94 \\
& Gender equality & 4 & 95 \\
\multirow{2}{*}{ Unstructured } & Vivisection & 4 & 188 \\
\hline Total & Gender equality & 4 & 232 \\
\hline
\end{tabular}

\section{Data Analyses}

Quality of discussions. In analyzing the quality of argumentative discussions, a speech turn was applied as a unit of analysis. A speech turn was defined as a single chat message that a student wrote and sent. Students' speech turns were classified into argument construction and discourse management categories (see Felton, 2004). The argument construction categories were argument and justified disagreement, and the discourse management categories were request, opinion, agreement/unjustified disagreement, comment, and off-task. These seven speech turn categories were mutually exclusive. The analytical categories are described below.

Argument construction categories. By putting forward speech turns in these two categories, students were able to broaden and deepen their argumentative knowledge on an issue.

1. Argument. This category includes speech turns in which students put forward arguments or explore arguments to support a claim or a statement.

2. Justified disagreement. When students put forward an argument against a claim or a statement, indicated a problem between two statements, or retracted a statement with a reason, the speech turn was classified as justified disagreement.

Discourse management categories. By the speech turns included in these categories, students maintained and/or directed the discussion. 
3. Request. All speech turns in which students asked for an argument, a counterargument, a clarification, a justifying example, or an opinion on a statement were classified as a request.

4. Opinion. When students expressed an opinion on an issue, took a position on a statement or issue, or changed their opinion on an issue, without giving reasons, the speech turn was classified as an opinion. For example, during an unstructured chat one student expressed an opinion that "animal experiments should be allowed" (speech turn 424).

5. Agreement/unjustified disagreement. If a student expressed agreement or disagreement with a statement without giving reasons, the speech turn was classified as agreement or an unjustified disagreement respectively.

6. Comment. Students' speech turns concerning the social, interaction, or task management of the discussion were classified as comments.

7. Off-task. This category includes speech turns which were unrelated to the task.

In determining the reliability of the analysis, $10 \%$ of the speech turns (61 in total) encompassing both modes of chat were cross-analysed by two judges. The inter-rater reliability of the analysis was .74 (Cohen's Kappa).

Example of the analysis of the chat discussion. Table 5 presents an extract from one debate on vivisection and an analysis of the speech turns exchanged between one student pair (Anna and Leo) using the structured chat tool. The students started their debate by stating their positions: Anna was against vivisection (speech turn 74) and Leo was in favour of it (speech turn 75). Next Anna asked Leo to support his position, and Leo responded to Anna by presenting his first argument (speech turns 77 and 78). Anna challenged this by presenting a counterargument 
(turn 80). Next, the students engaged in mutual argumentative discussion (speech turns 82-85).

When Leo expressed agreement with Anna (turn 87), Anna asked Leo to re-express his opinion

(either agree or disagree) on vivisection. Leo has not, however, changed his opinion.

Table 5.

Example of an Analysis of a Structured Chat on Vivisection (translated from Finnish)

\begin{tabular}{|c|c|c|c|}
\hline $\begin{array}{l}\text { No. of } \\
\text { speech } \\
\text { turn }\end{array}$ & Student & Speech turn & $\begin{array}{l}\text { Category of } \\
\text { speech turn }\end{array}$ \\
\hline- & - & Vivisection should be allowed (the already given main claim) & - \\
\hline 74 & Anna & I don't agree with statement [Vivisection should be allowed]. & $\begin{array}{l}\text { Unjustified } \\
\text { disagreement }\end{array}$ \\
\hline 75 & Leo & I agree with statement [Vivisection should be allowed]. & Agreement \\
\hline 76 & Leo & I would like to talk about statement [Vivisection should be allowed]. & Comment \\
\hline 77 & Anna & Can you give an argument for statement [Vivisection should be allowed]? & Request \\
\hline 78 & Leo & $\begin{array}{l}\text { I support statement [Vivisection should be allowed] because without } \\
\text { animal experiments we do not get new reliable knowledge for developing } \\
\text { new medicines and medical treatments. }\end{array}$ & Argument \\
\hline 79 & Leo & Your turn. & Comment \\
\hline 80 & Anna & $\begin{array}{l}\text { I attack statement [without animal experiments we do not get new reliable } \\
\text { knowledge for developing new medicines and medical treatments] because } \\
\text { the test results from animal experiments cannot be applied to humans } \\
\text { because of differences between the species. }\end{array}$ & $\begin{array}{l}\text { Justified } \\
\text { disagreement }\end{array}$ \\
\hline 81 & Anna & Your turn. & Comment \\
\hline 82 & Leo & $\begin{array}{l}\text { I attack statement [the test results from animal experiments cannot be } \\
\text { applied to humans because of differences between the species] because } \\
\text { without animal experiments medicines would have to be tested on humans. }\end{array}$ & $\begin{array}{l}\text { Justified } \\
\text { disagreement }\end{array}$ \\
\hline 83 & Anna & $\begin{array}{l}\text { I attack statement [without animal experiments medicines would have to be } \\
\text { tested on humans] because the test results of animal experiments tell, for } \\
\text { example, only about the injurious effects of certain chemical on a rat. } \\
\text { Thus, the results are not reliable. }\end{array}$ & $\begin{array}{l}\text { Justified } \\
\text { disagreement }\end{array}$ \\
\hline 84 & Leo & $\begin{array}{l}\text { Can you give an example to justify statement [the test results of animal } \\
\text { experiments tell, for example, only about the injurious effects to certain } \\
\text { chemical received by a rat. Thus, the results are not reliable.]? }\end{array}$ & Request \\
\hline 85 & Anna & $\begin{array}{l}\text { I would like to justify statement [the test results of animal experiments tell, } \\
\text { for example, only about the injurious effects to certain chemical received } \\
\text { by a rat. Thus, the results are not reliable.] by saying that some of the } \\
\text { injurious effects of chemicals occur only in humans, and thus do not occur } \\
\text { in laboratory animals. Additionally, the tested and approved chemicals } \\
\text { might alone or together with some other chemicals cause side effects for } \\
\text { which a pharmaceutical company is no longer responsible. }\end{array}$ & Argument \\
\hline 86 & Anna & Your turn. & Comment \\
\hline 87 & Leo & $\begin{array}{l}\text { I agree with statement [that some of the injurious effects of chemicals } \\
\text { occur only in humans, and thus do not occur in laboratory animals. . . ]. }\end{array}$ & Agreement \\
\hline 88 & Anna & What is your opinion about statement [Vivisection should be allowed]? & Request \\
\hline 89 & Leo & I agree with statement [Vivisection should be allowed]. & Agreement \\
\hline
\end{tabular}

Note: Templates are given in regular font, the students' contributions in italics, and the brackets indicate the previously expressed speech turn. 
Table 6 illustrates an analysis of an unstructured chat discussion between a student pair (Jenni and Mari). In the discussion, both students had the same opinion on vivisection: they do not favour animal experiments. For this reason, they only put forward arguments that supported their congruent antagonistic opinions on vivisection (speech turns 468-471). Jenni expressed (turn 472) reluctance to think up any argument contrary to her own opinion. Finally, Mari composed an argument that supported animal experiments.

Table 6.

Example of an Analysis of an Unstructured Chat on Vivisection (translated from Finnish)

\begin{tabular}{|l|l|l|l|}
\hline $\begin{array}{l}\text { No. of } \\
\text { speech } \\
\text { turn }\end{array}$ & Student & Speech turn & $\begin{array}{l}\text { Category of } \\
\text { speech turn }\end{array}$ \\
\hline 466 & Jenni & $\begin{array}{l}\text { Okay... What do you think about animal experiments? Should they be } \\
\text { allowed? }\end{array}$ & Request \\
\hline 467 & Mari & No. & $\begin{array}{l}\text { Unjustified } \\
\text { disagreement }\end{array}$ \\
\hline 468 & Jenni & I agree. One good reason is that they are not that useful. & Argument \\
\hline 469 & Mari & Right. Only rarely have some real results been reached. & Argument \\
\hline 470 & Jenni & $\begin{array}{l}\text { Exactly, and in spite of that that animals are continually tortured without } \\
\text { any good reason. However, I do not really love rats that much. }\end{array}$ & Argument \\
\hline 471 & Mari & $\begin{array}{l}\text { Yeah, I wouldn't take a big rat as a pet either, but nevertheless they also } \\
\text { have a right to a meaningful and nice life. }\end{array}$ & Argument \\
\hline 472 & Jenni & $\begin{array}{l}\text { You can say that again! I can't think of anything to say that would support } \\
\text { animal experiments. }\end{array}$ & Comment \\
\hline 473 & Mari & $\begin{array}{l}\text { I'm trying right now to think of an argument in supporting of it: veterinary } \\
\text { medicine needs animal experiments of course. }\end{array}$ & $\begin{array}{l}\text { Justified } \\
\text { disagreement }\end{array}$ \\
\hline
\end{tabular}

Counterargumentation strategies. When the students put forward a justified disagreement they often simultaneously used a counterargumentation strategy. To examine the quality of the students' counterargumentation strategies, the students' speech turns classified earlier as justified disagreements $(n=121)$ were sub-categorised into three categories (see Leitão, 2000):

\section{Supporting the opposite position}


This counterargumentation strategy was used when a person disagreed with his/her interlocutor by expressing a counterargument that supports a position opposed to that of his/her interlocutor. In the example below, Nora expressed a counterargument against Ari's statement. Ari was in favour of vivisection and he supported his position by the argument that he wants to take safe and tested medicines. Nora's counterargument (justified disagreement) was not directed at Ari's argument for vivisection; instead, she supported the opposing position (Vivisection should not be allowed) by saying that there are alternatives to animal experiments.

Ari: Vivisection should be allowed because I want to take safe and tested medicines. [speech turn 64]

Nora: I attack statement [I want to take safe and tested medicines] because - okay, everyone does, but there are more reliable alternatives to animal experiments. [turn 65]

\section{Questioning the truth of a claim or a statement}

This counterargumentation strategy was used when a person wanted to prove that the interlocutor's claim or statement is incorrect. In the example below, Iiro disagreed with the statement that test animals will suffer from experiments by presenting the counterargument that if test animals are given enough strong stuff before experiments they do not suffer from these experiments. Janita in turn questioned the truth of Iiro's statement by saying that animals are not given any other drugs because they could affect the test results. Consequently, Iiro's earlier argument was invalid, so he cannot use it any more.

Iiro: I attack statement [test animals suffer also from experiments] because test animals do not suffer if they get enough strong stuff in their veins. [turn 50] 
Janita: I attack the statement [test animals do not suffer if they get enough strong stuff to veins] because test animals are not given any other drugs because they could affect the test results. [turn 52]

\section{Questioning a reason-position link}

This counterargumentation strategy was used when a person wanted to indicate that the interlocutor's argument (or a reason) for his/her position is inefficient. The argument used may be true as such but its argumentative power to support the position in question is weak.

In the example below, taken from a structured chat discussion, Erika attacked the statement that the benefits from animal experiments are small by pointing out that through experiments we can produce new information about diseases and develop new medicines (a reason). The reason she presented indicates that she is for permitting animal experiments (a position).

Jari questioned the efficacy of the Erica's justification of animal experiments by putting forward a counterargument stating that animals are different to humans, and that medicines suitable for animals may be dangerous to humans. In this way Jari questioned Erika's implicit reason-position link, i.e., animals and humans are similar.

Erika: I attack statement [the benefit from experiments is very small] because we get new information about diseases and we can develop new medicines by animal experiments.[turn 13]

Jari: I attack statement [We get new information from diseases and we can develop new medicines by animal experiments] because animals are different to humans, and drugs which are suitable to for animals can be dangerous to humans. [turn 17] 
The inter-rater reliability of the analysis of the counterargumentation strategies $(10 \%$ of the data) was .71 (Cohen's Kappa).

Statistical analysis. The purpose of the statistical analyses was to clarify whether the independent variables, i.e., the mode of chat (structured vs. unstructured), topic (vivisection or gender equality), and gender (female/male) were associated with the dependent variables of the quality of argumentative discussion, i.e., the variables of argument construction, discourse management, and counterargumentation strategies. The dependent variables divided the speech turns into two categories according to whether the property in question appeared in the speech turn or not. Since the study interest was explanatory, that is, the independent and dependent variables were pre-determined and categorical in nature, the use of logit models (Kennedy, 1988) was an appropriate way to clarify the associations between the variables. (The statistical analyses were performed with PASW Statistics 18.)

Table 7.

Variables Used in the Logit Analyses

\begin{tabular}{|c|c|c|c|}
\hline \multirow[b]{2}{*}{$\begin{array}{l}\text { Independent } \\
\text { variables }\end{array}$} & \multicolumn{2}{|c|}{ Dependent variables } & \multirow[b]{2}{*}{$\begin{array}{l}\text { Counterargumentation strategy } \\
\text { variables }\end{array}$} \\
\hline & $\begin{array}{l}\text { Argument construction } \\
\text { variables }\end{array}$ & $\begin{array}{l}\text { Discourse management } \\
\text { variables }\end{array}$ & \\
\hline X11 Mode of chat & X1 Argument & X3 Request & $\begin{array}{l}\text { X8 Supporting the opposite } \\
\text { position }\end{array}$ \\
\hline X12 Topic & $\begin{array}{l}\text { X2 Justified } \\
\text { disagreement }\end{array}$ & X4 Opinion & $\begin{array}{l}\text { X9 Questioning the truth of a } \\
\text { claim or a statement }\end{array}$ \\
\hline X13 Gender & & $\begin{array}{l}\text { X5 Agreement/unjustified } \\
\text { disagreement } \\
\text { X6 Comment } \\
\text { X7 Off-task }\end{array}$ & $\begin{array}{l}\text { X10 Questioning a reason-position } \\
\text { link }\end{array}$ \\
\hline
\end{tabular}

Ten separate logit analyses were carried out. The dependent variable varied in the different analyses, while the independent variables were the same. The variables used in the analyses are described in Table 7 . The logit analyses were implemented by starting from the saturated model, in which all the possible main and interaction effects of the independent 
variables with the dependent variable were taken into account. Next, all the statistically nonsignificant parameters were dropped from the model step-by-step according to the hierarchy principle, by starting from the higher order terms and ending with the minimal acceptable model that fit with the data $(\mathrm{p}>.05)$ and included as few statistically significant parameters as possible. The minimal acceptable models of the logit analyses, including statistically significant parameters, are summarized in Appendix.

\section{Results}

\section{Quality of Argumentative Discussions in Structured and Unstructured Chat}

The students constructed arguments in $37 \%$ of their speech turns, and $63 \%$ of their speech turns belonged to the discourse management categories (see Table 8).

Table 8.

Frequencies and Proportions of Speech Turn Categories in Structured and Unstructured Chat

\begin{tabular}{|c|c|c|c|c|c|c|}
\hline \multirow{2}{*}{ Analysis categories } & \multicolumn{2}{|c|}{ Structured chat } & \multicolumn{2}{|c|}{ Unstructured chat } & \multicolumn{2}{|c|}{ Total } \\
\hline & $\mathrm{f}$ & $\%$ & $\mathrm{f}$ & $\%$ & $\mathrm{f}$ & $\%$ \\
\hline \multicolumn{7}{|l|}{ Argument construction: } \\
\hline Justified disagreement & 41 & 22 & 80 & 19 & 121 & 20 \\
\hline Argument & 28 & 15 & 78 & 19 & 106 & 17 \\
\hline Total & 69 & 37 & 158 & 38 & 227 & 37 \\
\hline \multicolumn{7}{|l|}{ Discourse management: } \\
\hline Comment & 54 & 29 & 124 & 30 & 178 & 29 \\
\hline Opinion & 5 & 3 & 67 & 16 & 72 & 12 \\
\hline Request & 33 & 17 & 28 & 7 & 61 & 10 \\
\hline $\begin{array}{l}\text { Agreement/unjustified } \\
\text { disagreement }\end{array}$ & 28 & 15 & 12 & 3 & 40 & 7 \\
\hline Off-task & 0 & 0 & 31 & 7 & 31 & 5 \\
\hline Total & 120 & 63 & 262 & 62 & 382 & 63 \\
\hline TOTAL & 189 & 100 & 420 & 100 & 609 & 100 \\
\hline
\end{tabular}

Argument construction. During the chat discussions 121 (20\%) of the students' speech turns were in the category justified disagreements and 106 (17\%) were arguments (Table 8).

Logit analysis 1 (Appendix) revealed that both topic (X12) and gender (X13) were associated with the number of arguments (X1): the students put forward more arguments in the 
discussions on gender equality than in the discussions on vivisection ( $21 \%$ vs. $14 \%$; Table 9$)$ and the female students produced more arguments than the male students (21\% vs. $13 \%$; Table 9$)$.

Logit analysis 2 (Appendix) showed also that the mode of chat (X11) was associated with the students' production of justified disagreements (X2). In addition, in logit analysis 2 (Appendix), an interaction effect of the mode of chat (X11) and topic (X12) on justified disagreement (X2) was found. This result indicated that during the unstructured chat discussions, justified disagreements (X2) were more common on the vivisection than gender equality topic ( $28 \%$ vs. $12 \%$; Table 9). However, during the structured chat discussions, the students expressed justified disagreements nearly as often on both topics (22\% vs. $21 \%$; Table 9$)$.

Table 9.

Significant Associations (Logit Analyses) of Argument Construction and Discourse Management

\begin{tabular}{|c|c|c|c|c|}
\hline \multirow[t]{2}{*}{ Dependent variables } & \multicolumn{4}{|c|}{ Independent variables } \\
\hline & $\begin{array}{l}\text { Main } \\
\text { effect: } \\
\text { Mode of } \\
\text { chat (X11) }\end{array}$ & $\begin{array}{l}\text { Main } \\
\text { effect: } \\
\text { Topic } \\
\text { (X12) }\end{array}$ & $\begin{array}{l}\text { Main } \\
\text { effect: } \\
\text { Gender } \\
\text { (X13) }\end{array}$ & $\begin{array}{l}\text { Interaction effect: } \\
\text { Mode of chat by Topic } \\
\text { (X11 by X12) }\end{array}$ \\
\hline \multicolumn{5}{|l|}{ Argument construction: } \\
\hline Argument (X1) & & $\begin{array}{l}\text { V: } 14 \% \\
\text { GE: } 21 \%\end{array}$ & $\begin{array}{l}\mathrm{M}: 13 \% \\
\mathrm{~F}: 21 \%\end{array}$ & \\
\hline $\begin{array}{l}\text { Justified disagreement } \\
\text { (X2) }\end{array}$ & $\begin{array}{l}\text { SC: } 22 \% \\
\text { UC: } 19 \%\end{array}$ & & & $\begin{array}{l}\text { Vivisection: } \\
\text { SC: } 22 \% \text {, UC: } 28 \% \\
\text { Gender equality: } \\
\text { SC: } 21 \% \text {, UC: } 12 \%\end{array}$ \\
\hline \multicolumn{5}{|l|}{ Discourse management: } \\
\hline Request (X3) & $\begin{array}{l}\text { SC: } 17 \% \\
\text { UC: } 7 \%\end{array}$ & & $\begin{array}{l}\text { M: } 7 \% \\
F: 13 \%\end{array}$ & \\
\hline Opinion (X4) & $\begin{array}{l}\text { SC: } 3 \% \\
\text { UC: } 16 \%\end{array}$ & & & \\
\hline $\begin{array}{l}\text { Agreement/unjustified } \\
\text { disagreement (X5) }\end{array}$ & $\begin{array}{l}\text { SC: } 15 \% \\
\text { UC: } 3 \%\end{array}$ & & & \\
\hline
\end{tabular}


Discourse management. To manage and maintain the discourse during the chat discussions 178 (29\%) of all the students' speech turns were in the category comments, 72 (12\%) were opinions, 61 (10\%) were requests, 40 (7\%) were agreements or unjustified disagreements, and $31(5 \%)$ were off-task speech turns (Table 8).

Logit analyses 3, 4 and 5 (Appendix) showed that the mode of chat (X11) was associated with the students' expressions of requests (X3), opinions (X4), and agreements or unjustified disagreements (X5). When the students were engaged in the structured chat environment, they presented both requests (17\% vs. $7 \%$; Table 9$)$ and agreements or unjustified disagreements $(15 \%$ vs. $3 \%)$ more often than in the unstructured chat environment. In contrast, the students presented more opinions in the unstructured than structured chat environment (16\% vs. $3 \%)$.

Gender (X13) was also found to be associated with requests (X3; analysis 3 in Appendix). The female students presented more requests than the male students during the chat discussions regardless of the mode of chat (13\% vs. $7 \%$; Table 9$)$.

Counterargumentation strategies. When the students presented justified disagreements $(n=121)$, they most often used "Questioning a reason-position link" (46\%; Table 10) and "Supporting the opposite position" (32\%) as their counterargumentation strategies. Their least used strategy was "Questioning the truth of a claim or a statement" (22\%). 
Table 10.

Frequencies and Proportions of Counterargumentation Strategies in Structured and Unstructured Chat

\begin{tabular}{|c|c|c|c|c|c|c|}
\hline \multirow{2}{*}{$\begin{array}{l}\text { Counterargumentation } \\
\text { strategy }\end{array}$} & \multicolumn{2}{|c|}{ Structured chat } & \multicolumn{2}{|c|}{ Unstructured chat } & \multicolumn{2}{|c|}{ Total } \\
\hline & $f$ & $\%$ & $f$ & $\%$ & $f$ & $\%$ \\
\hline $\begin{array}{l}\text { Questioning a reason- } \\
\text { position link }\end{array}$ & 16 & 39 & 39 & 49 & 55 & 46 \\
\hline $\begin{array}{l}\text { Supporting the opposite } \\
\text { position }\end{array}$ & 15 & 37 & 24 & 30 & 39 & 32 \\
\hline $\begin{array}{l}\text { Questioning the truth of } \\
\text { a claim or a statement }\end{array}$ & 10 & 24 & 17 & 21 & 27 & 22 \\
\hline Total & 41 & 100 & 80 & 100 & 121 & 100 \\
\hline
\end{tabular}

Logit analysis 8 (Appendix) revealed that both topic (X12) and gender (X13) were associated with the counterargumentation strategy "Supporting the opposite position" (X8): the students used this strategy more often in the chat discussions on vivisection than on gender equality ( $9 \%$ vs. $4 \%$; Table 11$)$, and this strategy was more common among the male than the female students ( $9 \%$ vs. 5\%; Table 11$)$.

Table 11

Significant Associations (Logit Analyses) of Counterargumentation Strategies

\begin{tabular}{|c|c|c|c|c|}
\hline Dependent variables & \multicolumn{4}{|c|}{ Independent variables } \\
\hline & $\begin{array}{l}\text { Main effect: } \\
\text { Mode of } \\
\text { chat (X11) }\end{array}$ & $\begin{array}{l}\text { Main effect: } \\
\text { Topic } \\
(\mathrm{X} 12) \\
\end{array}$ & $\begin{array}{l}\text { Main effect: } \\
\text { Gender } \\
(\mathrm{X} 13)\end{array}$ & $\begin{array}{l}\text { Interaction effect: } \\
\text { Mode of chat by Gender } \\
\text { (X11 by X13) }\end{array}$ \\
\hline \multicolumn{5}{|l|}{$\begin{array}{l}\text { Counterargumentation } \\
\text { strategy: }\end{array}$} \\
\hline $\begin{array}{l}\text { Supporting the opposite } \\
\text { position (X8) }\end{array}$ & & $\begin{array}{l}\mathrm{V}: 9 \% \\
\mathrm{GE}: 4 \%\end{array}$ & $\begin{array}{l}\text { M: } 9 \% \\
\text { F: } 5 \%\end{array}$ & \\
\hline $\begin{array}{l}\text { Questioning the truth of } \\
\text { a claim or a statement } \\
\text { (X9) }\end{array}$ & $\begin{array}{l}\mathrm{SC}: 5 \% \\
\mathrm{UC}: 4 \%\end{array}$ & & $\begin{array}{l}\text { M: } 4 \% \\
\text { F: } 5 \%\end{array}$ & $\begin{array}{l}\text { Male: } \\
\text { SC: } 1 \% \text {, UC: } 5 \% \\
\text { Female: } \\
\text { SC: } 9 \% \text {, UC: } 3 \%\end{array}$ \\
\hline $\begin{array}{l}\text { Questioning a reason- } \\
\text { position link (X10) }\end{array}$ & & $\begin{array}{l}\text { V: } 12 \% \\
\text { GE: } 7 \%\end{array}$ & & \\
\hline
\end{tabular}


Note: $\mathrm{SC}=$ Structured chat $\mathrm{UC}=$ Unstructured chat; $\mathrm{M}=$ Male; $\mathrm{F}=$ Female; $\mathrm{V}=$ Vivisection; $\mathrm{GE}=$ Gender equality; the unit of analysis was a speech turn $(N=609)$.

Logit analysis 9 (Appendix) showed that the mode of chat (X11) and gender (X13) had a statistically significant interaction effect on "Questioning the truth of a claim or a statement" (X9): the female students questioned the truth of a claim or a statement more often than the male students during the structured chat discussions ( $9 \%$ vs. 1\%; Table 11), whereas, during the unstructured chat discussions, the male students used this strategy more often than the female students (5\% vs. $3 \%$; Table 11$)$.

Logit analysis 10 (Appendix) also showed that topic (X12) was associated with the counterargumentation strategy "Questioning a reason-position link" (X10): this strategy was more common in the discussions on vivisection than those on gender equality ( $12 \% \mathrm{vs.} 7 \%$; Table 11).

\section{Discussion}

In this study, we focused on the question of whether secondary school students' argumentation can be promoted by structuring synchronous network interaction. The question was answered by examining the quality of argumentative discussions through argument construction, discourse management, and the use of counterargumentation strategies.

\section{Quality of Argumentative Chat Discussions and the Use of Counterargumentation}

\section{Strategies}

The results were in line with Hypotheses 1 and 2: The secondary school students were able to construct arguments and manage their argumentative chat discussions. They also used more constructive counterargumentation strategies (Questioning a reason-position link, Questioning the truth of a claim or a statement) than the unconstructive strategy "Supporting the opposite position" ( $68 \%$ vs. $32 \%$; Table 10$)$. 
The conclusion that secondary school students are able to construct arguments and manage their chat discussions is supported by the results that in $37 \%$ of their speech turns the students constructed arguments and presented justified disagreements, and in $17 \%$ of their speech turns they stimulated argumentative discussion by presenting requests, for example, for arguments, counterarguments, and justifications. The students' interaction was also quite counterargumentative as one-fifth of their speech turns were categorized as justified disagreements. There were also very few off-task speech turns (31 in total; 5\%) in the students' chat discussions.

Using a structured chat tool based on templates developed in particular to target argumentative and reciprocal dialogue, the students engaged in communication that was taskfocused in nature, as no off-task speech turns were observed. In the unstructured chat environment, the proportion of off-task talk was also low (7\%). The students were well-prepared for engagement in argumentative discussions as they had read topic-related texts and engaged in motivating activities before the discussions. The argumentative nature of the discussions and the small proportion of off-task talk suggest that in this study the students avoided the typical problems of chat discussions, such as lack of coordination and focus (Pimentel, Fuks, \& de Lucena, 2003), and difficulties in exploring and developing ideas and arguments (Burnett, 2003; Weger \& Aakhus, 2003).

\section{Associations of the Mode of Chat, Topic, and Gender with the Quality of Chat Discussions}

The results verified Hypothesis 3: The mode of chat, topic, and gender are associated with the quality of the discussions. These associations will be discussed in the following subsections: Argument construction, discourse management, and counterargumentation strategies. 
Argument construction. The results indicated that the proportion of arguments presented during the chat discussions was related to both the discussion topic and gender, but not to the mode of chat. The proportion of arguments proved higher when the discussion topic was gender equality compared to vivisection, although similar preparation phases were conducted in order to achieve a comparable basis for discussion on each topic. One explanation for this difference might be that gender equality is a common and everyday life topic. It does not necessarily presume more information than everyone has. On the contrary, vivisection as a discussion topic might not be so interesting and the students might not have enough prior knowledge on it. These results are in line with the study by Means and Voss (1996), who found that prior knowledge has an effect on the number of reasons generated.

The female students expressed more arguments than the male students (21\% vs. $13 \%)$. One explanation for this might be that, in general, female students both excel in verbal skills (e.g. OECD, 2009) and tend to be more diligent than male students; this could mean that they might also prepare themselves more carefully for discussions and hence be able to produce more arguments than male students. Females have also been found to produce more justifications than male students both online and offline (Herring \& Martinson, 2004). Both of the discussion topics used in the present study may also have inspired female students more than male students to present arguments.

The results of the statistical analyses indicated that the mode of chat and topic had an interaction effect on the proportion of justified disagreements in the students' discussions: justified disagreements were more common during the unstructured chat discussions on vivisection than that on gender equality ( $28 \%$ vs. $12 \%)$. During the structured chat discussions, the students put forward justified disagreements nearly as often on both topics ( $22 \%$ vs. $21 \%)$. 
These results suggest that a structured chat environment evokes counterargumentation also on topics that do not spontaneously provoke different conflicting viewpoints, like gender equality in this study. Topics of this kind do not by their nature offer debaters clear for or against positions. In the case of vivisection, the students probably found it easier to take either the role of a proponent or an opponent, favouring or rejecting animal experiments. Thus, a structured discussion seems to be an appropriate method for practicing argumentation also on topics which do not necessarily polarize debaters into the roles of proponents and opponents.

Zohar and Nemet (2002) point out that the nature of both the argumentative task and the topic affect the quality of argumentation. They differentiate tasks and topics according to features which cause persons to commit themselves to a position on a topic and to express opposing views. For example, asking for evidence or reasons for a causal phenomenon is a different task from asking a person to justify his/her opinion on an issue. In addition, the nature of the topic might affect the students' task performance. Hence it is crucial whether the topic to be discussed is authentic in nature, having a connection to the students' daily lives, or an arbitrary one without any such connection. In our study, both topics offered students the possibility to take a subjective stand. However, the nature of the dilemma contained in the topics may have been different. Gender-related topics have relevance to students' daily lives whether they are male or female, but these topics also invite objective as well as subjective examination. Vivisection, in turn, was not necessarily a daily topic for all the students. Maybe it was a more familiar topic for the female than male students, as several studies have reported that women have stronger environmental attitudes and behaviors compared to men (Zelezny, Chua, \& Aldrich, 2000), such as in relation to cosmetics (Kim \& Chung, 2011). Thus, female students' 
opinions on animal experiments, which have been strongly connected with the cosmetics industry, may also affect their argumentation.

Previous studies have shown that using authentic problems, which relate to students' lives, may foster students' argumentative abilities (Patronis, Potari, \& Spiliotopoulou, 1999; Zeidler, Sadler, Applebaum, \& Callahan, 2009). Udell (2007) found that adolescent girls' argument skills transferred only if they first focused on a personally relevant topic (teenage pregnancy), and then on a less personal topic (capital punishment). When designing future research, it would thus seem to be important to pay attention to discussion topics from the point of view of gender.

Discourse management. The students expressed more requests and unjustified agreements or disagreements, but fewer opinions, during the structured than unstructured chat. These results can be explained by the use of the templates during the structured chat: the structured chat tool included templates both for requesting (templates 1, 3, 5, 9, 14 in Table 3) and for expressing agreement or unjustified disagreement (templates 11 and 12).

The results also indicated that the female students presented more requests than the male students. This can be explained in accordance with the notion that female students seem to take on some responsibility for furthering knowledge. Female students have also previously been shown to focus more on collaboration than male students when they argue via chat (Carr, Cox, Eden, \& Hanslo, 2004). Furthermore, Li (2002) found that female students' interaction contained more requests for information than male students' interaction when an online learning environment was used.

Counterargumentation strategies. The results indicated that both topic and gender were associated with the students' counterargumentation strategies. When the discussion topic was 
vivisection compared to gender equality, the students more often supported the opposing position or questioned the reason-position link. These results suggest that the students may have had quite strong opinions on vivisection already before the chat discussions. During the discussions they merely sought to defend their own positions. In addition, the students seem to have had sufficient knowledge on vivisection to be able to question the links between reasons and positions. These results suggest that the students may be capable of engaging in informal reasoning if they have both enough knowledge and strong attitudes on the topic.

However, supporting the opposite position as a counterargumentation strategy is not a dialogical and constructive way to think critically because it does not bring the merit of the interlocutor's arguments into question (see Leitão, 2000). In this study, this strategy seems to be typical of male students in particular, albeit the difference between males and females ( $9 \% \mathrm{vs}$. $5 \%)$ was quite small.

The results also showed that the female students questioned the truth of a claim or a statement more often than their male peers during the structured chat discussions ( $9 \%$ vs. $1 \%$; Table 11). The male students, in contrast, used this counterargumentation strategy more often during the unstructured chat discussions (5\% vs. $3 \%$; Table 11$)$.

These results are in line with the findings of previous studies that male students are inclined to engage in conflict and they have a more assertive, competitive and adversarial conversation style compared to females (Carr et al., 2004; Herring, 1996). In the structured chat environment, the use of an adversarial conversation style by the male students was not supported because the structured chat guided them, not necessarily to attack but, first, to consider what they want to say, and then to choose a suitable template with which to express their statement. The templates were rather neutral, i.e., not very emotionally loaded. In contrast to the male students, 
the structured chat templates seemed to help the female students to employ a more adversarial communication style than they normally use. In other words, the templates render this kind of discussion style more socially acceptable for females. Thus, structuring a discussion seems to level out gender differences in communication. This can also make an argumentative discussion between males and females more explorative and thus more beneficial for students' learning. Explorative talk has been shown to promote co-construction of knowledge (Mercer, 1996). However, as observed by Robertson, Hewitt, and Scardamalia (2003), gender differences in communication styles should not be seen as a problem but as a facilitator of the construction of knowledge. The adversarial style of males can provide a challenging space for knowledge construction, while the collaborative style of females can facilitate the sharing of ideas and their further elaboration.

\section{Limitations of the Study}

The results of this study should be interpreted cautiously since the number of students was small. Another limitation is that the task might have caused cognitive overload for a novice arguer (see Kuhn \& Udell, 2003), as both argumentation and counterargumentation are demanding cognitive tasks. The students also had to manage several parallel processes: formulating one's own arguments, judging interlocutor's arguments, and managing the discussion. In addition to engaging in a demanding argumentation task, the students used structured chat for the first time. Thus, they might have needed more training in order to be able to use the structured chat tool more successfully as a learning aid.

\section{Implications of the study}

This study offers many possibilities to design and examine further the pedagogical structuring of collaborative argumentation and counter-argumentation processes when students 
engage in argumentative discussion in computer-based learning environments for the purpose of improving their understanding of specific learning issues. Despite the limitations of the study, it showed that structured and unstructured chat environments are suitable for argumentation-based studies of learning content in secondary school. It must, however, be borne in mind that not only the learning environment, but also the learning task and discussion topic are important factors in facilitating student engagement in effective argumentative discussion in order to co-construct knowledge.

Students' argumentation could be supported by more specific prompts than were used in this study. In further studies, it would be interesting to examine whether specific prompts designed to support, in particular, students' counter-argumentation during online discussions broaden and deepen their argumentation on a learning issue.

The study also showed that the discussion topic is an important factor when practicing argumentation. Even if structured chat seemed to moderate the effects of the topic to bring about constructive argumentative discussion among students, it did not take into account the genderrelated nature of the topic. Therefore, comparisons between discussions on female-related, malerelated, and gender-neutral topics from the point of view of collaborative argumentation are also an important area for future research.

\section{References}

Andriessen, J., Erkens, G., van de Laak, C., Peters, N., \& Coirier, P. (2003). Argumentation as negotiation in electronic collaborative writing. In J. Andriessen, M. Baker, \& D. Suthers (Eds.), Arguing to learn: Confronting cognitions in computer-supported collaborative learning environments (pp. 79-115). Dordrecht, The Netherlands: Kluwer Academic Publishers. 
Andriessen, J., \& Schwarz, B. (2009). Argumentative design. In N. Mueller Mirza, \& A-N. Perret-Clermont (Eds.), Argumentation and learning. Theoretical foundations and practices (pp. 145-174). Dordrecht, The Netherlands: Springer.

Arvaja, M., Rasku-Puttonen, H., Häkkinen, P., \& Eteläpelto, A. (2003). Constructing knowledge through a role-play in a web-based learning environment. Journal of Educational Computing Research, 28, 319-341.

Asterhan, C., \& Schwarz, B. (2007). The effects of monological and dialogical argumentation on concept learning in evolutionary theory. Journal of Educational Psychology, 99, 626639.

Baker, M., \& Lund, K. (1997). Promoting reflective interactions in a computer-supported collaborative learning environment. Journal of Computer Assisted Learning, 13, 175193.

Baker, M., Quignard, M., Lund, K., \& van Amelsvoort, M. (2002). Designing a computersupported collaborative learning situation for broadening and deepening understanding of the space of debate. In F. H. van Eemeren, J. A. Blair, C. A. Willard, \& A. F. Snoeck Henkemans (Eds.), Proceedings of the fifth conference of the international society for the study of argumentation (ISSA 2002) (pp. 55-61). Amsterdam, June 2002. Amsterdam, The Netherlands: Sic Sat Publications.

Blatchford, P., Kutnick, P., Baines, E., \& Galton, M. (2003). Towards a social pedagogy of classroom groupwork. International Journal of Educational Research, 39, 153-172.

Borg, W. R., \& Gall, M. D. (1989). Educational research: an introduction (5th ed.). White Plains, NY: Longman. 
Burnett, C. (2003). Learning to chat: tutor participation in synchronous online chat. Teaching in Higher Education, 8, 247-261.

Carr, T., Cox, L., Eden, A., \& Hanslo, M. (2004). From peripheral to full participation in a blended trade bargaining simulation. British Journal of Educational Technology, 35, $197-211$.

Chan, C. K. K. (2001). Peer collaboration and discourse patterns in learning from incompatible information. Instructional Science, 29, 443-479.

Condon S. L., \& Cech C. G. (1996). Functional comparison of face-to-face and computermediated decision making interactions. In S.C. Herring (Ed.), Computer Mediated Communication: linguistic, social and cross-cultural perspectives (pp. 65-80). Amsterdam, The Netherlands: Benjamins.

Corbel A., Girardot J., \& Jaillon P. (2002). DREW: a dialogical reasoning web tool. In A. Mendes Villas, J.A. Mesa Gonzalez, \& I. Solo de Zaldivar (Eds.), Educational technology: Vol 1. Proceedings of the international conference on ICT's in education (ICTE 2002) (pp. 516-521). Badajoz, Spain: Junta de Extremadura, Consejeria de education, cienca y technologia.

deLeeuw, N., \& Chi, M. T. H. (2003). Self-explanation: Enriching a situation model or repairing a domain model? In G. M. Sinatra, \& P. R. Pintrich (Eds.), Intentional conceptual change (pp. 55-78). Mahwah, NJ: Erlbaum.

Dillenbourg, P., \& Schneider, D. (1995). Mediating the mechanisms which make collaborative learning sometimes effective. International Journal of Educational Telecommunications, 1, $131-146$. 
Dons, C. F. (2008). “...it is a major challenge to guide pupils in a field they believe they master.” - student teachers on dealing with pupils' digital everyday. International Journal of Media, Technology, and Lifelong Learning, 4(2), 1-14.

Felton, M. K. (2004). The development of discourse strategies in adolescent argumentation. Cognitive Development, 19, 35-52.

Felton, M. K., \& Kuhn, D. (2001). The development of argumentive discourse skill. Discourse Processes, 32, 135-153.

Golanics, J. D., \& Nussbaum, E. M. (2008). Enhancing collaborative online argumentation through question elaboration and goal instructions. Journal of Computer Assisted Learning, 24, 167-180.

Golder, C., \& Pouit, D. (1999). For a debate to take place the topic must be debatable. In J. Andriessen, \& P. Coirier (Eds.), Foundations of argumentative text processing (pp. 137148). Amsterdam, the Netherlands: Amsterdam University Press.

Herring, S. C. (1996). Posting in a different voice: Gender and ethics in computer-mediated communication. In C. Ess (Ed.), Philosophical Perspectives on Computer-Mediated Communication (pp. 115-145). Albany, NY: SUNY Press.

Herring, S. C. (1999). Interactional coherence in CMC. Journal of Computer-Mediated Communication, 4(0). doi: 10.1111/j.1083-6101.1999.tb00106.x

Herring, S. C., \& Martinson, A. (2004). Assessing gender authenticity in computer-mediated language use. Journal of Language and Social Psychology, 23, 424-446.

Hirsch, L., Saeedi, M., Cornillon, J., \& Litosseliti, L. (2004). A structured dialogue tool for argumentative learning. Journal of Computer Assisted Learning, 20, 72-80. 
Hron, A., Hesse, F., Cress, U., \& Giovis, C. (2000). Implicit and explicit dialogue structuring in virtual learning groups. British Journal of Educational Psychology, 70, 53-64.

Hämäläinen, R. (2008). Designing and investigating pedagogical scripts to facilitate computersupported collaborative learning. University of Jyväskylä. Finnish Institute for Educational Research, 24.

Kennedy, J. J. (1988). Applying log-linear models in educational research. Australian Journal of Education, 32, 3-24.

Kim, H. Y., \& Chung, J-E. (2011). Consumer purchase intention for organic personal care products. Journal of Consumer Marketing, 28, 40-47.

Kuhn, D., \& Udell, W. The development of argument skills. Child Development, 74, 1245-1260.

Lazonder, A. W., Wilhelm, P., \& Ootes, S. A. W. (2003). Using sentence openers to foster student interaction in computer-mediated learning environments. Computers and Education, 41, 291-308.

Leitão, S. (2000). The potential of argument in knowledge building. Human Development, 43, $332-360$.

Leitão, S. (2003). Evaluating and selecting counterarguments. Studies of children's rhetorical awareness. Written Communication, 20, 269-306.

Li, Q. (2002). Gender and computer-mediated communication: an exploration of elementary students' mathematics and science learning. Journal of Computers in Mathematics and Science Teaching, 21, 341-359.

Linn, M. C., \& Elyon, B.-S. (2000). Knowledge integration and displaced volume. Journal of Science Education and Technology, 9, 287-310. 
Litosseliti, L., Marttunen, M., Laurinen, L., \& Salminen T. (2005). Computer-based and face-toface collaborative argumentation at secondary schools in England and Finland. Education, Communication, and Information, 5, 131-146.

Marttunen, M. (1997). Studying argumentation in higher education by electronic mail. Jyväskylä Studies in Education, Psychology and Social Research 127. University of Jyväskylä, Jyväskylä.

Marttunen, M., Laurinen, L., Litosseliti, L., \& Lund, K. (2005). Argumentation skills as prerequisites for collaborative learning among Finnish, French, and English secondary school students. Educational Research and Evaluation, 11, 365-384.

McAlister, S. (2004). Dialectics and design for online peer discussion. Unpublished $\mathrm{PhD}$ thesis, Institute of Educational Technology, Open University, UK.

McManus, M. M., \& Aiken, R. M. (1996). Teaching collaborative skills with a group leader tutor. Education and Information Technologies, 1, 75-96.

Means, L. M., \& Voss, J. F. (1996). Who reasons well? Two studies of informal reasoning among children of different grade, ability, and knowledge levels. Cognition and Instruction, 14, 139-178.

Mercer, N. (1996). The quality of talk in children's collaborative activity in classroom. Learning and Instruction, 6, 359-377.

Morgan, W., \& Beaumont, G. (2003). A dialogic approach to argumentation: Using a chat room to develop early adolescent students' argumentative writing. Journal of Adolescent \& Adult Literacy, 47, 146-157.

Nussbaum, E. M. (2008). Collaborative discourse, argumentation, and learning: Preface and literature review. Contemporary Educational Psychology, 33, 345-359. 
Nussbaum, E. M., \& Kardash, C. M. (2005). The effect of goal instructions and text on the generation of counterarguments during writing. Journal of Educational Psychology, 97, $157-169$.

OECD. (2009). Equally prepared for life? How 15-year-old boys and girls perform in school. Available at http://www.oecd.org/dataoecd/59/50/42843625.pdf.

O’Donnell, A. M., \& King, A. (Eds.). (1998). Cognitive perspectives on peer learning. Mahwah, NJ: Erlbaum.

Oehl, M., \& Pfister, H-R. (2010). E-collaborative knowledge construction in chat environments. In B. Ertl (Ed.), E-Collaborative knowledge construction: Learning from computersupported and virtual environments (pp. 54-72). Hershey, PA: Information Science Reference.

Patronis, T., Potari, D., \& Spiliotopoulou, V. (1999). Students' argumentation in decisionmaking on a socio-scientific issue: implications for teaching. International Journal of Science Education, 21, 745-754.

Paul, R. W., \& Elder, L. (2002). Critical thinking. Tools for taking charge of your professional and personal life. Upper Saddle River, NJ: Financial Times Prentice Hall.

Pimentel, M. G., Fuks, H., \& de Lucena, C. J. P. (2003). Co-text loss in textual chat tools. In P. Blackburn, C. Ghidini, R. M. Turner, \& F. Giunchiglia (Eds.), Modeling and using context. Lecture notes in computer science (Vol. 2680, pp. 483-490). Berlin: Springer.

Reiser, B. J., Tabak, I., Sandoval, W. A., Smith, B., Steinmuller, F., \& Leone, T. J. (2001). BGuILE: Strategic and conceptual scaffolds for scientific inquiry in biology classrooms. In S. M. Carver, \& D. Klahr (Eds.), Cognition and instruction: Twenty-five years of progress (pp. 263-305). Mahwah, NJ: Erlbaum. 
Robertson, J., Good, J., \& Pain, H. (1998). BetterBlether: the design and evaluation of a discussion tool for education. International Journal of Artificial Intelligence in Education, 9, 219-236.

Robertson, O., Hewitt, J., \& Scardamalia, M. (2003). Gender participation patterns in Knowledge Forum: an analysis of two graduate-level classes. Poster presented at the IKIT Summer Institute 2003, Toronto.

Schwarz, B. B. (2009). Argumentation and learning. In N. Mueller Mirza, \& A-N. PerretClermont (Eds.), Argumentation and learning. Theoretical foundations and practices (pp. 91-126). Dordrecht, the Netherlands: Springer.

Swann, J. (1992). Girls, boys and language. London: Blackwell.

Udell, W. (2007). Enhancing adolescent girls' argument skills in reasoning about personal and non-personal decisions. Cognitive Development, 22, 341-352.

van Amelsvoort, M. (2006). A space for debate. How diagrams support collaborative argumentation-based learning. Doctoral dissertation. ICO, Dutch Interuniversity Center for Educational Research. PrintPartners Ipskamp, Enschede.

Veerman A. (2000) Computer-supported collaborative learning through argumentation. Unpublished doctoral dissertation. Utrecht University, The Netherlands.

Veerman, A. L., Andriessen, J. E. B., \& Kanselaar, G. (2000). Learning through synchronous electronic discussion. Computers \& Education, 34, 269-290.

Walton, D. (2006). Fundamentals of critical argumentation. New York, NY: Cambridge University Press.

Webb, N. M. (1995). Group collaboration in assessment: Multiple objectives, processes, and outcomes. Educational Evaluation and Police Analysis, 17, 239-261. 
Weger, H., \& Aakhus, M. (2003). Arguing in internet chat rooms: Argumentative adaptations to chat room design and some consequences for public deliberation at a distance. Argumentation and Advocacy, 40, 23-38.

Weinberger, A., Ertl, B., Fischer, F., \& Mandl, H. (2005). Epistemic and social scripts in computer-supported collaborative learning. Instructional Science, 30, 1-30.

Wittrock, M. C. (1992). Generative learning processes of the brain. Educational Psychologist, $27,531-541$.

Zeidler, D. L., Sadler, T. D., Applebaum, S., \& Callahan, B. E. (2009). Advancing reflective judgment through socioscientific issues. Journal of Research in Science Teaching, 46, 74-101.

Zelezny, L. C., Chua, P-P., \& Aldrich, C. (2000). Elaborating on gender differences in environmentalism. Journal of Social Issues, 56, 443-457.

Zohar, A., \& Nemet, F. (2002). Fostering students' knowledge and argumentation skills through dilemmas in human genetics. Journal of Research in Science Teaching, 39, 35-62. 
Appendix

Summary of Logit Analyses (Minimal Acceptable Models)

\begin{tabular}{|c|c|c|c|c|}
\hline Parameter & Estim. & $S E$ & $z$ & $p$ \\
\hline \multicolumn{5}{|l|}{ Argument construction variables: } \\
\hline \multicolumn{5}{|l|}{ Analysis $1:(G 2=7.16, d f=5, p=.209)$} \\
\hline $\mathrm{X} 1$ (Argument) & 1.09 & .17 & 6.62 & $* * *$ \\
\hline X1 by X12 (Topic) & .53 & .22 & 2.36 & $*$ \\
\hline X1 by X13 (Gender) & .60 & .23 & 2.67 & $* *$ \\
\hline \multicolumn{5}{|l|}{ Analysis $2:(G 2=7.75, d f=4, p=.101)$} \\
\hline $\mathrm{X} 2$ (Justified disagreement) & 1.32 & .25 & 5.25 & $* * *$ \\
\hline X2 by X11 (Mode of chat) & .66 & .32 & 2.06 & * \\
\hline X2 by X12 (Topic) & -.08 & .35 & -.22 & ns. \\
\hline $\mathrm{X} 2$ by $\mathrm{X} 11$ by X 12 & -.95 & .44 & -2.17 & $*$ \\
\hline \multicolumn{5}{|l|}{ Discourse management variables: } \\
\hline \multicolumn{5}{|l|}{ Analysis 3: $(G 2=.19, d f=5, p=.999)$} \\
\hline X3 (Request) & 1.24 & .22 & 5.71 & $* * *$ \\
\hline X3 by X11 (Mode of chat) & 1.11 & .28 & 4.03 & $* * *$ \\
\hline X3 by X13 (Gender) & .78 & .30 & 2.61 & $* *$ \\
\hline \multicolumn{5}{|l|}{ Analysis $4:(G 2=7.89, d f=6, p=.246)$} \\
\hline X4 (Opinion) & 3.61 & .45 & 7.96 & $* * *$ \\
\hline X4 by X11 (Mode of chat) & -1.94 & .47 & -4.12 & $* * *$ \\
\hline \multicolumn{5}{|l|}{ Analysis $5:(G 2=2.56, d f=6, p=.862)$} \\
\hline X5 (Agreement/unjustified disagreement) & 1.75 & .21 & 8.54 & $* * *$ \\
\hline X 5 by X11 (Mode of chat) & 1.78 & .36 & 4.97 & $* * *$ \\
\hline \multicolumn{5}{|l|}{$\begin{array}{l}\text { Analysis } 6 \text { (X6 Comment) and } 7 \text { (X7 Off-task): } \\
\quad \text { (no statistically significant parameters) }\end{array}$} \\
\hline \multicolumn{5}{|l|}{ Counterargumentation strategy variables: } \\
\hline \multicolumn{5}{|l|}{ Analysis $8:(G 2=7.01, d f=5, p=.220)$} \\
\hline X8 (Supporting the opposite position) & 3.56 & .36 & 10.01 & $* * *$ \\
\hline X8 by X12 (Topic) & -.85 & .35 & -2.44 & $*$ \\
\hline X8 by X13 (Gender) & -.79 & .34 & -2.31 & * \\
\hline \multicolumn{5}{|l|}{ Analysis $9:(G 2=8.45, d f=4, p=.076)$} \\
\hline $\begin{array}{l}\text { X9 (Questioning the truth of a claim or a } \\
\text { statement) }\end{array}$ & 2.34 & .35 & 6.69 & $* * *$ \\
\hline X9 by X11 (Mode of chat) & 1.14 & .52 & 2.20 & $* *$ \\
\hline X9 by X13 (Gender) & 2.12 & 1.07 & 1.99 & * \\
\hline X9 by X11 by X13 & -2.72 & 1.18 & -2.31 & * \\
\hline \multicolumn{5}{|l|}{ Analysis $10:(G 2=3.14, d f=6, p=.791)$} \\
\hline X10 (Questioning a reason-position link) & 2.63 & .22 & 11.91 & $* * *$ \\
\hline X10 by X12 (Topic) & -.61 & .29 & -2.11 & $*$ \\
\hline
\end{tabular}

